\title{
PREPARATION TO OCCUPATION IN FRAMEWORK EDUCATIONAL PROGRAMS FOR PRE-SCHOOL EDUCATION AND IN THE EDUCATION OF CZECH KINDERGARTENS
}

Radmila BURKOVIČOV $\boldsymbol{A}^{*}$, Ostravská univerzita, Ostrava, Česká republika

Přijato: 28. 5. 2020/ Akceptováno: 2. 9. 2020

Typ článku: Teoretická studie

DOI: $10.5507 /$ jtie. 2020.018

Abstract: The article presents research results aimed at finding out whether and in what form the requirement formulated by Czech society: "familiarisation of children in pre-school education with the content of individual professions" is formulated in the currently valid Czech, Slovak, and Polish public framework educational program for pre-school education, and whether it is possible to implement the requirement according to the Czech educational program in the education of pre-school children in the Czech kindergarten. Qualitative analysis was applied to the educational programs. The data snippets from the segments of objectives, contents, and competencies were coded using coding units. Categories of the explicit or latent character emerged from coding in various dimensions: concept, examples, designation of activities, procedures, purpose, the meaning of profession; work items and materials; the name of the building in which the profession takes place; direct contact with professions in authentic environments. In all the framework educational programs analysed, an explicit form of the "requirement" is found in some categories. In the Czech kindergarten and according to the Czech framework educational programs, it may be implemented in pre-school children's education.

Keywords: occupation, framework educational program for pre-school education, kindergarten, pre-school education, child, category, dimension. 


\section{PŘíPRAVA NA POVOLÁNÍ V RÁMCOVÝCH VZDĚLÁVACÍCH PROGRAMECH PRO PŘEDŠKOLNÍ VZDĚLÁVÁNÍ A V EDUKACI ČESKÝCH MATEŘSKÝCH ŠKOL}

Abstrakt: Článek prezentuje výsledky výzkumu, jehož cílem bylo zjistit, zda a v jaké podobě je českou společností formulovaný požadavek: „seznamování dětí $v$ predškolním vzdělávání s obsahem jednotlivých povoláni" uveden v aktuálně platném českém, slovenském a polském státním rámcovém vzdělávacím programu pro předškolni vzdělávání, a zda lze požadavek podle českého vzdělávacího programu ve vzděláváni dètí předškolniho věku v české mateřské škole realizovat. $V e$ vzdělávacich programech se kvalitativní analýzou kódovaly v jednotkách kódováni datové úryvky ze segmentu cílư, obsahů a kompetencí. Z kódování vystoupily v rüzných dimenzích kategorie zjevného nebo latentního charakteru: pojem, přiklady, označování činností, postupy, účel, význam povolání; pracovní předméty a materiály; název objektu, v němž se povolání uskutečňuje; přmý kontakt s povoláními vautentických prostředich. Ve všech zkoumaných rámcových vzdělávacích programech se „požadavek" v některých kategoriích ve zjevné podobě nachází. V české MŠ jej lze ve vzděláváni dètí předškolního věku podle českého rámcového vzdělávacího programu realizovat.

Klíčová slova: povolání, rámcový vzdělávací program pro předškolní vzdělávání, mateřská škola, předškolní vzdělávání, dítě, kategorie, dimenze.

*Autor pro korespondenci: $\underline{\text { Radmila.Burkovicova@osu.cz }}$ 


\section{1 Úvod}

Většina dospělé populace zajišt’uje uspokojování svých potřeb, příp. potřeb svých nejbližších, prostřednictvím finančních prostředků získávaných vykonáváním povolání. Povolání jako pojem je definován v $§ 5$ písmeno f) zákona č. 435/2004 Sb. o zaměstnanosti, který ř́ká, že „se jedná o standardizovaný souhrn pracovních činností podle jejich obvyklého seskupeni na trhu práce, jejichž výkon předpokládá určitou odbornou a dalši zpưsobilost “. Odborná a další způsobilost k povolání se získává vzděláváním zejména ve školském systému, do něhož je zařazeno i vzdělávání předškolní v mateřských školách.

Článek prezentuje výsledky tří etap šetření. Nejprve bylo ve vybraných aktuálních českých školsko-politických dokumentech ke vzdělávání zjišt'ováno, zda zadávají českému předškolnímu vzdělávání úkoly v oblasti připravy na povolání a jak jsou tyto úkoly formulovány. Ve druhé části výzkumu bylo zjišt'ováno, zda a v jaké podobě jsou $\mathrm{v}$ aktuálně platném českém Rámcovém vzdělávacím programu pro předškolni vzdělávání (dále jen RVP PV) úkoly v oblasti připravy na povolání, identifikované v českých školskopolitických dokumentech, uvedeny. Zároveň bylo posuzováno, zda lze úkoly v oblasti prípravy na povoláni podle českého RVP PV ve vzdělávání dětí předškolního věku v české mateřské škole realizovat. Nakonec bylo zjišstováno, zda se obdobný požadavek vyskytuje i ve slovenském a polském kurikulu, a v jaké podobě. Analýza školsko-politických dokumentů těchto států týkající se př́ípravy na povolání, tak jako v českém prostředí, a posuzování realizace přípravy na povolání v praxi mateřských škol těchto států, součástí výzkumu nebyly.

\section{Povolání a jedinec}

Povolání je předmětem nejen pracovně právní problematiky, ale i ekonomiky, sociologie a dalších věd. Podle Havlové je povolání subjektivně chápáno jako specifická aktivita, jíž se zajišt'uje živobytí, a která zároveň může uspokojovat individuální potřebu seberealizace (1996, s. 7). Objektivně povolání vymezuje místo jednotlivce v komplexu činností, ze kterých se skládá moderní ekonomika společnosti (Hlad’o, 2008, s. 76). Pracovní činnosti, jež jsou v jednotlivých povoláních vykonávány, jsou v ČR strukturovaně popisovány nap̌r. v Národni soustavě povolání. Proces realizace pracovní činnosti je ovlivňován množstvím kontextových faktorů kvality vzdělávání, které do problematiky vstupují, jako jsou např. vývoj společnosti, různá hodnotová orientace společenských skupin (Vlček \& Mužík, 2012, s. 142).

Jedinec je od narození obklopen výsledky povolání materiálního i nemateriálního charakteru. Bezděčně, nezáměrně, bezprostředně se s povoláními, s jejich účelem a výsledky v různých životních situacích seznamuje, mnohdy souběžně s uvědomováním si jejich významu pro svou osobu. Poznatky o povoláních po celý život průběžně, podle životních podmínek a událostí, v nichž se nalézá, více či méně vědomě doplňuje, rekonstruuje, inovuje. Přímý nebo nepř́mý vliv na získávání poznatků jedince o povoláních mají lidé ze společenské vrstvy, do níž se jedinec narodil, v níž prožil dětství, do níž je sociálně začleněn. Vlček uvádí, že myšlenkové vzorce jsou ovlivňovány nejen těmito specifickými sociálními, ale také geografickými, historickými, náboženskými, politickými aj. faktory predstavujícími prostředí, ve kterém jedinec vyrůstal a sbíral své životní zkušenosti (2015, s. 401). Záměrně je jedinec seznamován s těmi povoláními, která jsou v komunitě, jíž je součástí, hodnocená jako potřebná, jichž si komunita váží. Oceňování povolání se v historii proměňovalo, bylo poplatné době, a nebylo vždy úměrné 
úsilí, jež jedinec či jedinci vykonávání povolání věnovali, ani potřebě konkrétního povolání ve společnosti či jeho významu pro společnost. Hlad’o píše, že některá povolání však společnost v lidských dějinách hodnotila jako významná vždy a umožňovala těm, jež je vykonávali, získat výhodnější společenskou pozici (2008, s. 76).

Povolání byla a jsou ukazatelem sociálního a ekonomického statusu jedince. Někteří rodiče proto napřimují pozornost svých dětí již v předškolním věku k povoláním, jež se podle nich $\mathrm{v}$ konkrétní společnosti těší určité prestiži; $\mathrm{k}$ těm, o nichž jsou přesvědčeni, že jejich vykonávání dítěti přinese $v$ budoucnu ekonomický prospěch, nebo $\mathrm{k}$ těm, jež mají tradici $\mathrm{v}$ rodině a rodiče si přjí, aby $\mathrm{v}$ nich jejich děti pokračovaly. Kromě činitelů společenských působí jako vnější činitel podněcující poznávání jednotlivých povolání kontext historické, kulturní, ekonomické situace regionu, v němž jedinec žije a působí i distribuční pravidla konkrétní společnosti. Podle svého povolání se lidé také dobrovolně spolčují, poněvadž je spojuje stejný nebo obdobný zájem o tytéž záležitosti, problémy, procesy; rozumí si, protože v komunikaci používají podobné pojmy a odborné termíny k vyjádření.

Realizace povolání, tedy vykonávání určitého okruhu prací, vyžaduje soubor potřebných schopností, dovedností, vědomostí a osobnostních rysů (Hlad’o, 2008, s. 76), které člověk získává vzděláváním. Získání konkrétních komponent kompetencí v současné době reprezentuje nabytí určitého druhu a stupně vzdělání, které představuje kvalifikaci potřebnou k činnostem ve většině konkrétních povolání, a tím možnost získání pracovního místa a uplatnění. Pro výběr povolání jedince je jedním z nejvýznamnějších kritérií hospodářské prostředí regionu, $\mathrm{v}$ němž se rozhodl jedinec trvale bydlet.

Tak, jako téměř vše v lidské společnosti, mají i povolání svůj vývoj. Nejprve vznikala i zanikala v souvislosti s proměnou způsobu získávání potravy a potřebou jejího složení lidskou společností. V některých povoláních se přetvářely činnosti a proměňoval se poměr její fyzické a psychické složky. Paleta společnosti potřebných povolání a jejich charakter se bude s největši pravděpodobností proměňovat i v budoucnu (Frey, Oborne, 2013, s. 38; NIP, s. 144). Jako jedna z oblastí, v nichž povolání nejsou bezprostředně ohrožená, je uváděno vzdělávání (Frey, Oborne, 2013, s. 148).

\section{Filozofie vzdělávání dětí $\mathbf{k}$ povolání v MŠ}

Dítě př̌dškolního věku se s některými povoláními setkává denně, s jinými občas a $\mathrm{s}$ některými jen mimořádně, a to podle životních podmínek, které mu rodiče $\mathrm{z}$ hlediska místa bydliště, způsobu rodinného života i bydlení, stylu společně tráveného volného času, apod. umožní. Realizaci setkání s povoláními mohou aktivizovat i potřeby, zájmy dětí a úspěch dítěte při prosazování jejich uspokojování u rodičů.

Předškolní vzdělávání není vázáno konkrétním učivem, proto mohou být děti v předškolním věku seznamovány i s povoláními, která jsou již historií. Avšak v průběhu celého období, které předchází době, kdy se dnešní dítě předškolního věku bude rozhodovat, jak by se mohlo již jako dospělý účastnit ekonomiky státu, by dospělí měli dítěti zprostředkovávat dětskému chápání př́stupné informace o povoláních, která se v naší společnosti vyskytují dnes, a o nichž se domníváme, že budou existovat $i$ $\mathrm{v}$ budoucnu, rozvinout $\mathrm{u}$ dítěte $\mathrm{v}$ předškolním věku paletu jím zvládnutelných dovedností k některým povoláním se vztahujícím, a trvale podněcovat a uspokojovat dítětem projevený zájem o některá povolání. 
Programovým východiskem pro vzdělávání v mateřských školách a př́pravných třídách je Rámcový vzdělávaci program pro predškolni vzdělávání.

\section{Pojetí RVP PV a vybraných rámcových vzdělávacích programů pro předškolní vzdělávání}

\subsection{Pojeti RVP PV}

RVP PV ve své platné verzi z roku 2018 má celkem 50 stran. Prezentuje koncepci společného vzdělávání dětí, podpory pedagogické autonomie škol a profesní odpovědnost učitelů za výsledky vzdělávání dětí. Doplňuje a podporuje rodinnou výchovu a v úzké vazbě na ni pomáhá zajistit dítěti prostředí $\mathrm{s}$ dostatkem mnohostranných a přiměřených podnětů $\mathrm{k}$ jeho aktivnímu rozvoji a učení se. Vymezuje hlavní požadavky, podmínky a pravidla pro vzdělávání dětí prredškolního věku $\mathrm{v}$ institucích zařazených do sítě škol a školských zařízení v ČR.

RVP PV stanovuje elementární vzdělanostní základ, na který má navázat základní vzdělávání. Má definovány hlavní principy, cíle rámcové i dílčí, klíčové kompetence (k učení; k řešení problémů; komunikativní; sociální a personální; činnostní a občanské), jež jsou provázány se vzdělávacím obsahem a uplatněním získaných vědomostí a dovedností v praktickém životě a formulují jejich očekávanou úroveň dětmi na konci předškolního období.

Hlavním cílem RVP PV je usnadňovat dítěti jeho další životní i vzdělávací cestu, rozvíjet osobnost dítěte, podporovat jeho tělesný rozvoj a zdraví, jeho osobní spokojenost a pohodu, napomáhat mu v chápání okolního světa a motivovat jej $\mathrm{k}$ dalšímu poznávání a učení, stejně tak i učit dítě žít ve společnosti ostatních, přibližovat mu normy a hodnoty touto společností uznávané, vytvářet dobré předpoklady pro pokračování ve vzdělávání a za všech okolností maximálně podporovat individuální rozvojové možnosti dítěte, aby dospělo k takové úrovni, která je pro dítě individuálně dosažitelná (MŠMT, 2018, s. 7).

Vzdělávací obsah je uspořádán do pěti vzdělávacích oblastí: biologické, psychologické, interpersonální, sociálně-kulturní a environmentální, které jsou nazvány: Dítě a jeho tělo, Dítě a jeho psychika, Dítě a ten druhý, Dítě a společnost a Dítě a svět. Každá vzdělávací oblast má definovány velmi volně dílčí vzdělávací cíle, vzdělávací nabídku a zahrnuje i předpokládané dílčí výstupy. Specifikem RVP PV je, že u vzdělávací nabídky jsou definována i rizika vzdělávacího úsilí učitele. A poněvadž vychází ve své koncepci $\mathrm{z}$ respektování individuálních potřeb a možností dítěte, je základním východiskem i pro př́pravu vzdělávacích programů pro děti se speciálními vzdělávacími potřebami.

V přípravě školních vzdělávacích programů pak požaduje uplatňování integrovaného př́ístupu prostřednictvím integrovaných bloků, které nabízejí dítěti vzdělávací obsah v přirozených souvislostech, vazbách a vztazích a jež mají vycházet ze života dítěte, být pro ně smysluplné, zajímavé a užitečné. Realizace pak poskytuje dítěti širokou škálu různých aktivit a nabízí mu hlubší prožitek. Dítě tak získává činnostní výstupy komponenty kompetencí, tedy mnohostranné, dokonalé a prakticky využitelné poznatky a dovednosti, informace o hodnotách, a vytváŕí si postoje. Získaná zkušenost je komplexnější a stává se pro dítě snáze uchopitelnou a prakticky využitelnou (MŠMT, 2018). 


\subsection{Pojetí zahraničnich vybraných rámcových vzdělávacich programů pro předškolni vzdělávání}

Přibližně stejnou cestu $\mathrm{v}$ dimenzích velmi podobného politického a společenskoekonomického vývoje prošla předškolní pedagogika ve 2. polovině 20. století v České, Slovenské a Polské republice. V současné době se již každá z předškolních teorií i praxí v České, Slovenské a Polské republice ubírá vlastním směrem. Poněvadž jsou odborné kontakty mezi pedagogy zabývajícími se předškolní pedagogikou těchto států nadále intenzívně udržovány, je účelné seznámit se s pojetím polského a slovenského rámcového vzdělávacího programu pro předškolní vzdělávání státní úrovně v tomto nejbližším zahraničí a zjistit, zda se český požadavek $\mathrm{v}$ nich v nějaké podobě objevuje. Zjištěná data rozšiří naše poznání, doplní teorii předškolní pedagogiky o informace týkající se stavu výzkumného předmětu $\mathrm{v}$ zahraničí.

Slovenský státní rámcový vzdělávací program Štátny vzdelávací program pre predprimárne vzdelávanie v materských školách ${ }^{l}$ (dále také ŠVP PV) má v poslední verzi z roku 2016 celkem 112 stran. Uvádí jako hlavní cíl výchovy a vzdělávaní v mateřské škole dosáhnout optimální kognitivní, senzo-motorické a socio-citové úrovně jako základu pro školní vzdělávání v ZŠ a pro život ve společnosti; a 11 cílů všeobecných. Na rozdíl od českého a polského vzdělávacího programu definuje stupeň vzdělání, které dítě absolvováním vzdělávání podle tohoto dokumentu získá a předkládá profil absolventa v elementárních základech kompetencí komunikačních; matematických a kompetencí v oblasti vědy a techniky; digitálních; kompetencí učit se, řešit problémy, tvořivě a kriticky myslet; sociálních a personálních; občanských a pracovních.

Obsah vzdělávání vymezuje $\mathrm{v}$ následujících vzdělávacích oblastech: Jazyk a komunikace; Matematika a práce s informacemi; Člověk a př́roda; Člověk a společnost; Člověk a svět práce; Umění a kultura a Zdraví a pohyb. Každá vzdělávací oblast má definován hlavní cíl. „V souladu s filozofii osobnostně orientované předškolni pedagogiky a koncepci tvořivě humanistické výchovy je ditě pojímáno jako aktivni subjekt, který poznává v interakci a komunikaci s dětmi a dospělými. " (Lipnická \& Jirešová, 2007, s. 19).

Polský rámcový vzdělávací program celostátní úrovně Podstawa programowa wychowania przedszkolnego dla przedszkoli oraz innych form wychowania przedszkolnego ${ }^{2}$ (dále také PPP) má ve verzi 2018 celkem 8 stran a je závazným programovým dokumentem pro vzdělávání a výchovu dítěte $\mathrm{v}$ polských předškolních zařízeních. Hlavní cíl předškolního vzdělávání uvedený ve vzdělávacím programu prezentuje základní myšlenku koncepce předškolního vzdělávání v Polsku, a to podpořit celkový rozvoj dítěte a uspokojit jeho potřeby prostřednictvím procesu péče, výchovy a výuky, aby dosáhlo školní zralosti a začalo se v této první fázi vzdělávání učit. Poněvadž pouze „učení se“ dítěte umožňuje jemu samému objevit své vlastní schopnosti, smysl pro jednání a shromažd’ovat zkušenosti.

Cíle jsou rozpracovány do 17 požadavků nikoliv ve vztahu $\mathrm{k}$ dítěti, ale ve vztahu $\mathrm{k}$ učitelům včetně požadavku rozvoje dítěte $\mathrm{v}$ cizím jazyce a poznávání jiných kultur,

\footnotetext{
1 Státní vzdělávací program pro předškolní vzdělávání v mateřských školách

2 Základní program pro předškolní vzdělávání pro mateřské školy a další formy předškolního vzdělávání
} 
od čehož jsou osvobozeny děti se speciálními vzdělávacími potřebami. Jsou uvedeny podmínky a způsoby realizace požadavků.

A program rozpracovává, co se od dítěte na konci předškolního období očekává v komponentách kompetencí formulovaných v činnostní podobě, které vypovídají o obsahové náplni v oblasti emocionální (celkem 11), sociální (cca 9), kognitivní (cca 23) a v oblasti tělesného rozvoje (cca 9).

Všechny tři výše uvedené vzdělávací programy jsou rámcovými vzdělávacími programy státní úrovně, které jsou závazné a jimiž se řídí vzdělávání dítěte v předškolním věku v předškolních zařízeních uvedených států. Jsou veřejnými dokumenty. Ve všech je uveden: hlavní cíl; dílčí cíle, které jsou vyjádřeny volně; obsah, který má formu vzdělávací nabídky; a předpokládané, dítětem na konci předškolního období dosažené komponenty kompetencí. Formulace hlavních i dílčích cílů jsou v rámcových programech rozdílné, poněvadž vycházejí z historického vývoje předškolního vzdělávání v každé zemi, jsou ovlivněny specifiky současné situace států a neznámou budoucností a jsou sestaveny na základě rozdílných obecně didaktických východisek. Obsahová nabídka předškolního vzdělávání reflektuje více vlivů, např. preferované směrování společností (tak je např. ve slovenském ŠVP PV zařazená vzdělávací oblast „Matematika a práce s informacemi“). Základní vzdělávací metodou je „učení se objevováním“ a praktickou činností, jimiž dítě získává osobní zkušenost a prvotní poznatky a jimiž je respektováno na jedné straně dítě se všemi rysy charakteristickými pro svůj věk, se svou individualitou, spontánní aktivitou a zaujetím a jak uvádí Harbo, na druhé straně uspořádané edukační prostředí (1991, s. 253). Poněvadž zejména komponenty kompetencí, které si dítě osvojuje, jsou primárně závislé na charakteru vzdělávacího obsahu a připravené pedagogické situaci, mají vzdělávací programy zejména charakteristické rysy vstřícného modelu (Harbo, 1991, 254).

Jsou tak vytvořeny podmínky, aby každý pedagogický tým, jakákoliv odborná pracovní skupina, profesní sdružení či každý jednotlivý učitel mohli vytvářet a realizovat svůj vlastní školní vzdělávací program.

\section{Metodologie}

Edward O. Wilson: „Věda nemůže uchopit komplexnost světa jinak, než tak, že ji nejprve rozloži na „přirozené elementy. “(1993, s. 63)

Výzkumná otázka zněla: Jak je RVP PV v oblasti úkolů př́pravy na povoláni propojen s českými školsko-politickými dokumenty ke vzdělávání a pedagogickou praxí české MŠ, a jak jsou tyto úkoly řešeny ve vybraných cizích aktuálních rámcových vzdělávacích programech?

\section{Cíli výzkumného šetření bylo:}

(1) Zjistit, zda a v jaké podobě aktuální české školsko-politické dokumenty ke vzdělávání zadávají českému předškolnímu vzdělávání úkoly v oblasti př́pravy na povolání a jak jsou tyto úkoly formulovány.

(2) Zjistit, zda a v jaké podobě jsou uvedeny $v$ aktuálně platném českém rámcovém vzdělávacím programu pro předškolní vzdělávání státní úrovně úkoly v oblasti připravy na povolání identifikované v českých školsko-politických dokumentech. 
(3) Při analýze českého RVP PV zároveň posoudit, zda lze připravu na povolání podle českého RVP PV ve vzdělávání dětí předškolního věku v české mateřské škole realizovat. (4) Zjistit, zda a v jaké podobě jsou ve slovenském a polském aktuálně platném rámcovém vzdělávacím programu pro předškolní vzdělávání státní úrovně úkoly $\mathrm{v}$ oblasti př́pravy na povolání identifikované $\mathrm{v}$ českých školsko-politických dokumentech, uvedeny.

Cíle byly řešeny v uvedené posloupnosti.

\section{Výzkumný soubor}

Výzkumný soubor tvořily:
A) aktuální české školsko-politické dokumenty ke vzdělávání zadávají českému předškolnímu vzdělávání úkoly v oblasti př́pravy na povolání
B) Vybrané vzdělávací programy státní úrovně

Ad A) K prostudování, zda a v jaké podobě aktuální české školsko-politické dokumenty ke vzdělávání zadávají českému předškolnímu vzdělávání úkoly v oblasti př́pravy na povolání a jak jsou tyto úkoly formulovány; byly po důkladném zvážení vybrány následující dokumenty:
a) Strategie vzdèlávaci politiky České republiky do roku 2020
b) Národní iniciativa Prümysl 4.0
c) Dlouhodobý záměr vzdělávání a rozvoje vzdělávací soustavy České republiky 2011-2015
d) Nová opatření na podporu odborného vzdèlávání 2013
e) Opatreni Dlouhodobého zámèru vzdèlávání a rozvoje vzdèlávací soustavy České republiky na obdobi 2015-2020
f) Zákon č. 561/2004 Sb. o předškolním, základním, středním, vyšším odborném a jiném vzdělávání

Podle Gavory se texty vybírají na základě předem určených charakteristik a výsledkem výběru je určitý systém textů $(2015$, s. 353$)$.

Charakteristiky, podle nichž byly dokumenty vybrány, byly:

- c české školsko-politické dokumenty ke vzdělávání, a to aktuální;

- $\quad$ z nich pak dokumenty zadávající českému předškolnímu vzdělávání úkoly $\mathrm{v}$ oblasti prípravy na povolání.

Ad B) Vzdělávací programy státní úrovně

a) RVP PV ve své platné verzi z roku 2018

b) Polský rámcový vzdělávací program celostátní úrovně Podstawa programowa wychowania przedszkolnego dla przedszkoli oraz innych form wychowania przedszkolnego

c) Slovenský státní rámcový vzdělávací program Štátny vzdelávací program pre predprimárne vzdelávanie v materských školách

Z hlediska systému byly nejprve analyzovány školsko-politické dokumenty, následně aktuální český RVP PV a v zájmu rozšiřrení poznání i rámcové vzdělávací programy státní úrovně slovenský a polský.

Výzkumný soubor tvoří relevantní texty vybrané intencionálně (Guest, et al. (2012, s. 7-8).

\section{Výsledky}




\subsection{Výsledky 1. etapy výzkumu}

Ad (1)

Dokument Strategie vzdělávaci politiky České republiky do roku 2020 (dále Strategie 2020) mj. vyzývá k prověření východisek, na jejichž základě je v České republice organizováno vzdělávání. Smysl vzdělávání lze podle dokumentu Strategie 2020 v nejobecnější podobě vyjádřit prostřednictvím čtyř jím definovaných hlavních cílů, přičemž jedním z nich je připrava na pracovni uplatnění (2014, s. 8). Dokument českému předškolnímu vzdělávání konkrétně úkoly v oblasti připravy na povoláni nezadává, cíle však směruje k celému školskému systému, tedy i k předškolnímu vzdělávání.

Podle materiálu Národní iniciativa Průmysl 4.0 (dále NIP) je cestou k uchování povolání, prŕípadně ke vzniku nových profesí (NIP, s. 54) mj. prohloubení vazby obsahu vzdělávání na potřeby praxe (NIP, s. 121). Požadavek př́pravy na povolání je zde vyjádřen latentně (Gavora, 2015, s. 355-357).

Strategický centrální dokument pro oblast vzdělávání, který jednou za čtyři až pět let vydává MŠMT Dlouhodobý záměr vzděláváni a rozvoje vzdělávaci soustavy České republiky 2011 - 2015 (dále jen Záměr) v části II. 1. 1. 3 Obsah předškolního vzdělávání a jeho změny na léta 2011 až 2015 požaduje začít již od mateřských škol s polytechnickou výchovou (s. 18). V na něm navazujících Nových opatřeních na podporu odborného vzděláváni 2013, v části označené I2), je pro vzdělávání dětí předškolního věku jako návrh opatření uvedeno: ,seznamováni dětí v predškolním vzděláváni s obsahem jednotlivých povolání v souladu s Rámcovým vzdělávacím programem pro předškolní vzdéláváni" (s. 4) (dále již jen ,požadavek“). Jde o obsahový požadavek, zadání vznesené k učitelům mateřských škol.

V Opatření Dlouhodobého záměru vzdělávání a rozvoje vzdělávaci soustavy České republiky na obdobi 2015-2020 v oblasti Předškolní vzdělávání je zadání již pozměněno. V oddíle A. 6.4 je formulováno: ,podpořit manuální zručnost a prvky polytechnické výchovy ve vzdělávání $v$ mateřských školách (s. 14). Takto definovaný cíl je však souvztažný s požadavkem definovaným v Nových opatřeních $v$ předchozím období. Rozvíjení manuální zručnosti dítěte nemůže probíhat bez souběžných doprovázejících informací dítěti o tom, ve kterém povolání lze nabývanou zručnost uplatnit a využít, což je zcela v souladu s obecnými cíli vzdělávání zákona č. 561/2004 Sb. § 2 odst. 2a) v aktuálním znění, jímž je mj. rozvoj osobnosti člověka, který bude vybaven ...pro ... výkon povolání nebo pracovní činnosti... Podle § 33 zákona č. 561/2004 Sb. se předškolní vzdělávání dále mj. podílí na osvojení základních životních hodnot. Připravuje dítě pro život ve společnosti, v níž uplatnění v povolání je jednou z hodnot základních.

Zatímco „Nová opatřeni" Zámèru 2011-2015 „požadavek“ seznamovat dětí v predškolním vzdělávání s obsahem jednotlivých povolání zřetelně definuje, v Záměru 2015-2020 je tento ,požadavek“ vyjádřen latentně (Gavora, 2015, s. 355-357).

6.2 Výsledky 2. etapy výzkumu

Ad (2)

V této etapě výzkumu bylo zjišt'ováno, zda a v jaké podobě jsou v aktuálně platném českém rámcovém vzdělávacím programu pro předškolní vzdělávání státní úrovně úkoly voblasti prípravy na povolání identifikované v českých školsko-politických dokumentech, uvedeny.

Ad (3) 
Při analýze českého RVP PV bylo zároveň posuzováno, zda lze přípravu na povolání podle něj ve vzdělávání dětí předškolního věku v české mateřské škole realizovat.

„Požadavkem“ je tedy myšleno: „seznamování dětí v předškolním vzdělávání s obsahem jednotlivých povoláni “ tak, jak jej pro české předškolní vzdělávání formulovala česká společnost v Nových opatřeních Záméru 2011 až 2015. Představuje předmět výzkumu. Poněvadž „požadavek“ obsahuje zpřesnění „, v souladu s $R V P P V$ “, byla tedy v českém vzdělávacím prostředí výzkumná pozornost věnována RVP PV, a to poslední platné verzi z roku 2018.

\subsubsection{Použitá výzkumná metoda a postup}

Stanovený cíl byl řešen kvalitativní analýzou. V jejím průběhu byl uplatněn konstituční př́stup (Gavora, 2015, s. 366). Ke kódování byly vybrány segmenty: oblast cílů (A), obsahu (B) a kompetencí (C).

Jednotkami ke kódování se staly dílčí cíle vzdělávání (I) v segmentu výběru $\mathrm{A}$, tematická vzdělávací nabídka (II) v segmentu výběru $\mathrm{B}$ a očekávané výstupy vzdělávání (III) vztahující se k segmentu výběru C. „Jednotkou analýzy může být jakýkoliv textový element: slovo, slovní spojení, odsek, téma. "(Gavora, 2015, s. 352).

Separátní (každý jeden) dílčí cíl, téma a předpokládaná osvojená komponenta kompetence jsou datovými úryvky, v nichž docházelo ke kódování. Opakovaně se objevující kódy v datových úryvcích byly seskupeny do kategorií, jimiž jsou:

- $\quad$ pojem povolání (1), příklady povolání (2), označování činností v povolání (3); postupy v povolání (4); pracovní předměty a materiály (5); účel povolání (6); význam povolání (7); uvedení názvu objektu, v němž se povolání uskutečňuje (8); př́mý kontakt s povoláními v autentických prostředích (9).

Podle Gavory vytvoření kódového schématu (seznam kódů a jejich popis) předchází samotnému kódování (2015, s. 358).

Poněvadž předmět zkoumání nárokuje ,seznamováni“", je v datových úryvcích sledována i dimenze kategorií (Gulová, Šíp, 2013, s. 51). Proces analýzy byl vratný, cyklický, zdokonalující (Strauss, Corbin, 1999, s. 110). Z kódování vystoupil dvojí charakter identifikovaných kategorií v programech. Jednak jde o kategorie manifestní, zjevné, jednak mají kategorie podobu latentní, skrytou (Gavora, 2015, s. 355-357).

\section{2 .3}

Identifikace „požadavku“ $v$ českém RVP PV - získaná data a posuzování, zda lze př́pravu na povolání podle něj ve vzdělávání dětí př̌edškolního věku v české mateřské škole realizovat.

„Interpretace výzkumnika je při analýze výzkumu zcela zásadni. Výzkumník může výsledek interpretovat pres vlastnosti a dimenze, které se promitly do názvu kategorie. " (Gulová \& Šíp, 2013, s. 51).

V RVP PV v segmentu výběru $\mathrm{C} v$ jedné z klíčových kompetencí, a to v kompetenci $\mathrm{k}$ učení, $\mathrm{v}$ datovém úryvku: ,ditě ukončujici predškolni vzděláváni má elementární poznatky o světě lidí, kultury, prrirody i techniky, který dítě obklopuje, o jeho rozmanitostech a proměnách" (s. 11) jsou obsaženy všechny kategorie analýzy, a to v latentní formě a mají dimenzi poznatku. Poněvadž „každá analýza latentního obsahu je 
originálním interpretačním činem “ (Gavora, 2015, s. 357), pomáhají k označení latentní formy kategorií zkušenosti pedagogické praxe.

V jednotce kódování (I) v segmentu A ve vzdělávací oblasti 5.1 Dítě a jeho tělo v datových úryvcích: ,osvojení si poznatkù o těle a jeho zdraví, o pohybových činnostech a jejich kvalitě; osvojeni si poznatkù a dovedností důležitých k podpoře zdraví, bezpeči “ (s. 15) lze v latentní formě identifikovat všechny kategorie analýzy a učitelka je může v aktivitě dítěti zprostředkovat ve zřejmé podobě. A jak je ve zjevné podobě uvedeno, mají dimenzi poznatků a dovedností.

V segmentu výběru (B) v jednotce (II) je relevantní datový úryvek: „manipulační činnosti a jednoduché úkony s předměty, pomůckami, nástroji, náčiním a materiálem " (s. 15). Je zřejmé, že učitelka při zprostředkovávání této obsahové nabídky pro aktivity dětí pracovní předměty a materiály (5) pojmenuje; uvede i př́ílad, ve kterém povolání (1) se nástroje, materiál, náčiní použivají (2); co a jak dospělý v povolání vykonává $(3,4)$; a informace dítěti zasadí do širšího rámce sdělení účelu (6) a významu (7) povolání pro společnost, př́padně přidá další související data (8). Pokud podmínky dovolí, zprostředkuje je (9). Datový úryvek skrývá dimenzi dovednosti.

V datovém úryvku: ,činností zaměrených k poznávání lidského těla a jeho částí “ (s. $15)$ v téže jednotce (II) jsou skryty všechny kategorie analýzy. Při realizaci této vzdělávací nabídky je více než pravděpodobné, že děti budou seznámeny také s ochranou před úrazy a nemocemi poznávaných částí lidského těla, s povoláními (1), která je pomáhají léčit a $\mathrm{v}$ př́padě možností bude naplněná $i$ kategorie (9), a to vše v dimenzi poznatku.

Identifikovat ve zjevné podobě kategorii: pracovní předměty a materiály (5), a to $\mathrm{v}$ dimenzi manuální dovednosti lze $\mathrm{v}$ části datového úryvku v jednotce kódování (III) vztahující se k segmentu výběru C: „zvládat jednoduchou obsluhu a pracovni úkony (postarat se o hračky, pomúcky, uklidit po sobě, udržovat pořádek, ... (s. 16). V další části datového úryvku: ..."zvládat jednoduché úklidové práce a práce na zahradè apod. "(s. 16) lze identifikovat ve skryté podobě všechny kategorie analýzy a učitelka je může všechny dítěti zprostředkovat. Ve slovním spojení: „zvládat pracovni úkony“ se skrývá dimenze manuální dovednosti.

$\mathrm{V}$ datovém úryvku: ,znát základni pojmy uživané ve spojení se zdravím, s pohybem a sportem “ (s. 16) jsou opět v latentní podobě obsaženy všechny kategorie analýzy, a to v dimenzi znalosti a záleži pouze na tom, zda a v jakém rozsahu je učitelka ve hře či didakticky zacílené aktivitě dětem zprostředkuje.

V obsahové oblasti RVP PV 5.2. Dítě a jeho psychika nebyly v jednotce kódování (I) v segmentu výběru A identifikovány datové úryvky, jež by obsahovaly některé z vyvozených kategorií.

V jednotce kódování (II) segmentu výběru $\mathrm{B} \mathrm{v}$ obsahové oblasti v datovém úryvku: „výlety do okoli (do prírody, návštěvy dètských kulturnich akcí apod.) “ (s. 21) se skrývají všechny kategorie analýzy. Uvedené mimořádné aktivity jsou v MŠ běžně realizovány.

Je jasné, že při doporučených metodách v jednotce výběru (II)... „společné diskuse, rozhovory, individuálni a skupinová konverzace (vyprávěni zážitkư, př̉iběhủ, vyprávění podle skutečnosti i podle obrazového materiálu, podle vlastni fantazie, sdělováni slyšeného druhým apod.; komentování záżitki̊ a aktivit, samostatný slovní projev na určité téma... (s. 12) může učitelka zařadit téma o jednotlivých povoláních, $v$ nichž by byly zrealizovány ve 
zřejmé podobě všechny kategorie analýzy. V datovém úryvku jsou všechny kategorie analýzy obsaženy ve skryté formě.

V jednotce kódování (III), tedy v samostatně formulovaných očekávaných výstupech vzdělávání vztahujících se $\mathrm{k}$ segmentu výběru $\mathrm{C}$, v datovém úryvku: „popsat situaci (skutečnou, podle obrázku); rozhovor o výsledku pozorováni “ (s. 19) jsou v latentní formě obsaženy všechny kategorie. Př̆i realizaci je opět podstatné, kam učitelka děti zavede, která povolání a v jakém rozsahu je umožní dětem pozorovat, jak dětské poznání ukotví v širším kontextu účelu, významu pozorovaného povolání pro děti a jejich rodiče, atd. s ohledem na sledované kategorie. Intelektuální a komunikační dovednost jako komponenty kompetence komunikativní a kompetence $\mathrm{k}$ učení se zde skrývají v latentní formě. I datový úryvek: ,námětové hry a činnosti“ "(s. 19) obsahuje v latentní podobě kromě kategorie (9) všechny kategorie ostatní a tyto kategorie mají potenciál být učitelkou naplněny. V latentní formě se zde skrývá dimenze poznatek.

Ve vzdělávací oblasti RVP PV 5.3 Dítě a ten druhý bychom téměř ve všech segmentech výběru mohli kategorie analýzy identifikovat $v$ latentní formě a předpokládat, že je učitelka v duchu požadavku naplní. To ale v př́padě, že učitelka bude „požadavek“ znát a ten se stane $\mathrm{v}$ její vzdělávací práci ukazatelem.

Datový úryvek: seznamováni se světem lidí, kultury a uměni "(s. 25) vzdělávací oblasti RVP PV 5.4 Dítě a společnost, který je uveden v analyzované jednotce (I), mající vztah $k$ segmentu výběru A, obsahuje opět v latentní podobně všechny kategorie analýzy. Jestliže se však má dítě v průběhu jakékoliv aktivity s něčím pouze „seznámit“, není dána její kontrolovatelná dimenze.

V latentní podobě je možné identifikovat všechny kategorie analýzy v analyzované jednotce (II) segmentu výběru B v datovém úryvku ,poslech pohádek, př́iběhủ, veršů, hudebnich skladeb a písní, sledování dramatizací, divadelnich scének, a to i mimo MS̆“" (s. 25), a dále $\mathrm{v}$ jednotce (II) $\mathrm{v}$ datovém úryvku: „hry zaměřené k poznávání a rozlišsováni rưzných společenských roli (mj. profesní role) "(s. 25). Které kategorie analýzy by byly v edukaci dětí předškolního věku v MŠ naplněny, záleží na tom, jakým obsahem a v jaké šíři by je učitelka konkretizovala a dětem zprostředkovala zejména proto, že RVP PV $\mathrm{v}$ obou datových úryvcích uvádí $\mathrm{v}$ užším slova smyslu prostředky vzdělávání. Nenaplněná by zůstala ve druhém př́padě kategorie (9), poněvadž RVP PV zde uvádí hry. Poznávání a rozlišování představuje dimenzi poznatku. 
$\mathrm{V}$ jednotce (II) v datovém úryvku: ...,„tematické hry seznamujicí dítě s různými druhy zaměstnáni, remesel a povolání, a v souvislosti s tím i ...s rưznými pracovnimi činnostmi a pracovními prédměty, ... “(s. 26) je identifikovatelná kategorie: pojem povolání (1), jež je na tomto místě v českém vzdělávacím programu výslovně uvedena. I když není v kurikulu v tomto datovém úryvku vyjádřen „obsah“, jež je součástí „,požadavku“, dítě se v př́ipadě realizace datového úryvku s obsahem povolání zcela jistě setká. Může tak být konstatováno, že „požadavek“ “ je na tomto místě v českém vzdělávacím programu obsažen. Vedle pojmu „povolání“ jsou v datovém úryvku ještě uvedeny pojmy řemesla a zaměstnání. S rozdíly mezi pojmy zaměstnání, řemesla a povolání dítě předškolního věku zpravidla neseznamujeme. Dále lze v datovém úryvku identifikovat kategorii: označování pracovních činností v povolání (3) a v latentní formě je vyjádřena kategorie: postupy v povolání (4). Pokud se dítě bude prostřednictvím hry seznamovat s postupem ,pečení chleba“..., pak se v průběhu seznamování seznámí i s kategorií, která je v datovém úryvku vyjádřená ve zjevné podobě, a to s pracovními předměty a materiálem (5) - pec; mouka, voda, máslo. Seznamování bude obsahovat i účel povolání (6) - upéci chléb); význam povolání (7) - abychom se mohli najíst; případně i uvedení názvu, účelu zařízení, objektu, v němž se povolání uskutečňuje (8) - pekárna, pro pečení chleba, rohlíků, koláčů; v pekařské peci. Poněvadž se má dítě ,seznámit..., a to prostřednictvím hry“, nebude se tak dít $\mathrm{v}$ prímém kontaktu $\mathrm{s}$ povoláními $\mathrm{v}$ autentických prostředích (9). Dimenze seznámení neklade na dítě žádné nároky.

Datový úryvek: „dodržovat (dodržuje) pravidla her a jiných činnosti““ (s. 26) v jednotce kódování (III) vztahující se $\mathrm{k}$ segmentu výběru $\mathrm{C}$ může představovat výsledek, $\mathrm{k}$ němuž dítě dospělo na základě vzdělávacího obsahu, $\mathrm{v}$ němž by byly identifikovány kategorie analýzy 1 až 8 ve zréejmé podobě, a pokud nepůjde o hru, ale o ,jiné činnosti“ i s kategorií (9). Úryvek představuje dimenzi dovednost s aktivní vůlí.

Ve vzdělávací oblasti RVP PV 5.5 Dítě a svět lze konstatovat, že ve zřejmé a ani v latentní podobě není možné kategorie $\mathrm{v}$ jednotce analýzy (I) segmentu výběru $\mathrm{A}$ identifikovat.

V datovém úryvku: „přirozené pozorováni blizkého prostředí a života v něm...; návštěvy obchodü, návštěevy důležitých institucí, budov a dalšich pro ditě významných objektü “ (s. 28) v jednotce analýzy (II) segmentu B uvedena nabídka skrývá všechny kategorie analýzy. Lze důvodně předpokládat, že pokud učitelka s dítětem navštíví př́kladně obchod $\mathrm{v}$ malé obci, čímž realizuje kategorii analýzy: př́mý kontakt $\mathrm{s}$ povoláními v autentických prostředích (9), že uvede, označí, budovu, do níž děti vstoupily, popíše její vybavení a účel (8), pojmenuje, kdo všechno v obchodě pracuje (2), kdo sedí za pokladnou (1), co (3) a jak (4) v obchodě vykonává a čím (5), jaký účel (6) a význam (7) mají tato povolání pro dítě a jeho rodinu. Na vycházce uvede, ...že významným objektem vedle zámku v obci je funkční kovárna s tvořícím kovářem, pekárna s pečicími pekaři, zahradnictví se zahradníky pečujícími (nejen) o prostor před MěÚ. Realizace obsahu datového úryvku dítěti umožňuje vytvářet si autentické zkušenosti (dimenze) ve spojení s poznatky (dimenze) ve skutečných prostředích (9).

Další datový úryvek v analyzované jednotce (II): „sledování událostí v obci a účast na akcich, kteréjsou pro dítě zajímavé “ (s. 26) opět skrývá všechny identifikované kategorie. Podle místních podmínek může představovat akce hasičů zahrádkářů, chovatelů v obci. Není možné povolání hasiče, at' už profesionálního či dobrovolného, v souvislosti s jejich 
činnostmi, které předvádějí a do nichž zpravidla i pozorující děti předškolního věku zapojují (9), nepojmenovat (1), neuvést jednotlivé pozice hasičů pro zásah (2). V situaci se nedá jinak, než popsat, co hasiči dělají (3), jak (4) a proč to dělají (6), s jakým náčiním a nářadím (5) a jaký to prrináší celé společnosti užitek (7). Umístění stanice hasičů v menších obcích zná po vycházkách každé předškolní dítě starší tř́ let (8).

Podle datového úryvku: „... při hrách a aktivitách na téma dopravy, dopravnich situací, kterých se ditě běžně účastni "(s. 28) v téže analyzované jednotce je dítě seznamováno s povoláními, na která si „hraji““. A i v tomto př́padě jsou všechny kategorie latentně kromě kategorie (9) identifikovatelné. Naopak kategorie (9) je zjistitelná v jednotce (II) ve zrejejé podobě při realizaci datového úryvku: „Pracovní, pěstitelské a chovatelské činnosti “ (s. 29), jež dítě může v prostř̌edí k tomu uzpůsobeném, vykonávat. Učitelku pak přimo obsah vybízí k: pojmenování povolání $(1,2)$, v nichž se činnosti vykonávají (3), popsat, jak se vykonávají (4), které pracovní nářadí a náčiní jsou k jejich realizaci potřeba (5), vyvodit jejich účel (6) a význam (7). I v tomto datovém úryvku z analytické jednotky (II) se nacházejí všechny kategorie v latentní formě. V posledních třech výše uvedených datových úryvcích závisí jejich dimenze ve zřejmé podobě na učitelkou formulovaných cílech pro hru nebo jinou aktivitu.

Z hlediska identifikovaných kategorií analýzy ,požadavku“ je významný datový úryvek v analyzované jednotce (III) segmentu výběru C: „mít povédomí o širším společenském, věcném, př́rodním, kulturním i technickém prostředí i jeho dění v rozsahu praktických zkušeností a dostupných praktických ukázek v okolí dítěte" (s. 29). Poněvadž se $\mathrm{v}$ datovém úryvku uvádí dimenze praktická zkušenost, dítě by $\mathrm{k}$ ní mělo dospět zkoušením, manipulováním, experimentováním, a to mj. v technickém prostředí, kdy je zřejmá analyzovaná kategorie (9). Prostřednictvím těchto operací by dítě mělo dospět $\mathrm{k}$,povědomí“, tedy k dimenzi jednoduchého poznatku. Ostatní kategorie analýzy jsou skryté, ale ve vztahu ke kategorii (9) v procesu předškolního vzdělávání jasně předpokládané. Stejně tak v datovém úryvku: ,vědět, kam se v př́ipadě potřeby obrátit o pomoc"(s. 29) identifikujeme všechny kategorie analýzy a dá se předpokládat, že dítě nejen bude seznámeno, ale $\mathrm{v}$ dimenzi vědomosti obsáhne všechny kategorie analýzy.

\subsection{Výsledky 3. etapy výzkumu}

Ad (4)

Identifikace předmětu se uskutečnila následně ve slovenském státním rámcovém vzdělávacím programu Štátnom vzdelávacom programe pre predprimárne vzdelávanie v materských školách, který je celostátně platný od 1.9. 2016, a poté v současnosti platném polském státním rámcovém vzdělávacím programu Podstawa programowa wychowania przedszkolnego dla przedszkoli oraz innych form wychowania przedszkolnego ve verzi 2018.

\subsubsection{Identifikace ,požadavku“ ve slovenském ŠVP PV - ziskaná data}

Zaměřeným segmentem ke kódování slovenského vzdělávacího programu pro předškolní vzdělávání je obsahová B oblast 5.5 Vzdelávacia oblast' Človek a svet práce (s. 74), jednotka ke kódování (II) nazvaná: Remeslá a profesie (s. 79). Zde je sledovaný „požadavek“ vyjádřen zjevně, a to v datovém úryvku: „Učitel'ka sa venuje diskusii o rôznych tradičných remeslách (s. 79), v němž lze identifikovat kategorii analýzy: pojem povolání (1). V další části datového úryvku:,,...zameriava sa na opis postupu prípravy 
vybraných produktov... “ (s. 79) identifikujeme ve zjevné podobě kategorii: označování činností v povolání (3); postupy v povolání (4), v obou př́ípadech v dimenzi představ. V další části datového úryvku: „...pričom sa sústred’uje na aktuálnu skúsenost’ deti “ (s. 79) identifikujeme dimenzi formulovanou v komponentě zkušenosti. V celém tomto zadání lze vysledovat $\mathrm{v}$ latentní podobě kategorie analýzy: pracovní předměty a materiály (5); účel (6) a význam povolání (7). Ve vzdělávacím programu je následně ve zjevné formě uvedená i kategorie analýzy: př́íklady povolání (2), a to cihlářství, hrnčírství, tkalcovství, košíkářství (s. 79). Jedná se tedy zejména o př́klady historických povolání. A kromě skryté kategorie analýzy (9) je v latentní podobě př́tomna i kategorie (8).

V jednotce analýzy (III) lze v datovém úryvku: „Pozná (dítě) niektoré tradičné remeslá. "(s. 79) jsou ve skryté podobě obsaženy všechny kategorie analýzy v dimenzi poznatku.

Ve druhém datovém úryvku, v segmentu výběru $\mathrm{B}$, jednotce analýzy (II): „,Učitelka sa venuje diskusii o rôznych súčasných povolaniach (s. 80)...identifikujeme ve zřejmé podobě kategorii analýzy: pojem povolání (1). Úryvek pokračuje: (Ǔc.),, ...moderuje diskusiu o aktuálních predstavách detí o obsahu pracovnej náplne vybraných profesii " (s. 80). Lze v něm v latentní formě identifikovat kategorie analýzy: označování činností (3) a postupů v povolání (4) v dimenzi představy. Ve zřejmé podobě jsou vyjmenovány: př́íklady povolání (2) „lekár, šofér, učitel, policajt (a iné) “(s. 80). Poněvadž je požadováno: (Uč.) ,sústred’uje sa na ... a význam vybraných profesii “(s. 80) jde o zřejmou podobu kategorie analýzy: účel a význam povolání (6), (7); a jsou v latentní formě vyjádřeny i kategorie analýzy $(5,8$ a 9). Z pokračování datového úryvku: ...,pričom sústred'uje pozornost' detí na ich aktuálne skúsenosti s danými povolaniami “" (s. 80) je ve zřejmé podobě identifikována dimenze zkušenost.

Ve formulaci analyzované jednotky (III), která spadá do segmentu C: (Dítě) „Pozná základnú pracovnú náplñ vybraných profesii. " (s. 80) lze identifikovat ve zřejmé podobě kategorie analýzy: pojem povolání (1), př́klady povolání (2), označování činností v povolání (3); postupy v povolání (4); pracovní předměty a materiály (5), ostatní kategorie $\mathrm{v}$ podobě skryté, a to vše $\mathrm{v}$ dimenzi poznatku.

Některé kategorie ve zrrejmé podobě, jiné v podobě latentní lze identifikovat $\mathrm{v}$ segmentu výběru (B) i v analytických jednotkách (II) Technologie výroby, Materiály a jejich vlastnosti, Konstruování, Uživatelské zručnosti, a to v dimenzi vědomostí a zkušeností.

Je možno konstatovat, že významová kategorie „požadavku“ „pojem povolání“ je ve slovenském vzdělávacím programu uvedena. Zároveň pro povolání v rámcovém vzdělávacím programu nacházíme ekvivalent „profese“.

\subsubsection{Identifikace „požadavku“ v polském PPP - ziskaná data}

$\mathrm{V}$ současném aktuálním polském rámcovém vzdělávacím programu pro předškolní vzdělávání nalezneme „požadavek“ ve zjevné podobě. $\mathrm{V}$ segmentu výběru $\mathrm{C}, \mathrm{v}$ analytické jednotce III, je uvedeno: „,(Dítě) označuje profese vykonávané rodiči a lidmi z bezprostředního okolí, vysvětluje, co dělá osoba vykonávajicí povoláni" (s. 10). Identifikujeme ve zřejmé podobě kategorie: pojem povolání (1), př́klady povolání (2), označování činností v povolání (3); postupy v povolání (4), a to v dimenzi znalost. $\mathrm{V}$ utajené formě se $\mathrm{k}$ požadavku vážou kategorie: účel a význam povolání $(5,6)$ i kategorie (7) a (8). 
Možnost „požadavku“ obsahuje dále bod 11 „Úkolů mateřských škol“ v datovém úryvku: „Vytváŕeni podminek umožňujicich bezpečné, nezávislé zkoumáni technických prvků v životním prostředí, konstruování, kutilství, plánováni a provádění záměrných činností, prezentování výtvorů vlastní práce. “(s. 6). Zkoumání, konstruování dítěte...atd. nese potenciál všech kategorií analýzy.

\section{Diskuse}

K identifikaci úkolů českého předškolního vzdělávání $\mathrm{v}$ oblasti prípravy na povolání byly vybrány výše uvedené aktuální české školsko-politické dokumenty. „Požadavek“ seznamovat dětí $v$ predškolním vzdělávání s obsahem jednotlivých povolání zřetelně definuje dokument „Nová opatřeni “ Záměru 2011-2015 (dále jen Záměr). V Záměru 20152020 je tento ,požadavek" vyjádřen latentně.

Ve zjevné podobě se „požadavek“ formulovaný v Záměru nachází v RVP PV v segmentu výběru $\mathrm{B}$ v jednotce (II) vzdělávací oblasti 5.4 Dítě a společnost v datovém úryvku: ... „tematické hry seznamujici ditě s různými druhy zaměstnání, řemesel a povolání, a v souvislosti s tím i ...s různými pracovnimi činnostmi a pracovními predměty, ... “(s. 26). Lze identifikovat kategorii: pojem povolání (1), jež je na tomto místě v českém vzdělávacím programu výslovně uveden, a to v požadované dimenzi seznámení tak, jak jej uvádí Záměr. I když datový úryvek nepromlouvá o obsahu povolání, pokud učitelka přistoupí $\mathrm{k}$ jeho realizaci, bude jej konkretizovat a s ním také všechny další kategorie analýzy, které mají v datovém úryvku skrytou podobu, kromě kategorie analýzy (9), poněvadž datový úryvek doporučuje tematické hry.

Ve vzdělávání dětí předškolního věku v české MŠ lze „požadavek“ realizovat, a to plněním tematických nabídek RVP PV, naplňováním doporučených metod a prostředků v užším slova smyslu a zejména př́pravou her a didakticky zacílených aktivit s odpovídajícími náměty.

Ve slovenském ŠVP PV byl „požadavek“ identifikován ve zjevné podobě v segmentu výběru $\mathrm{B}, \mathrm{v}$ jednotce výběru (II), jimž odpovídá vzdělávací oblast 5.5 „Človek a svet práce“, a to ve vzdělávací podoblasti Remeslá a profesie. V latentní i zřejmé podobě by bylo možné „požadavek“ identifikovat i v dalších podoblastech segmentu výběru B. Dále byl požadavek identifikován ve zřejmé podobě ve většině analyzovaných kategorií v segmentu výběru $\mathrm{C}$, v analytické jednotce (III) v dimenzích poznatku, zkušeností a představ.

V polském vzdělávacím programu je požadavek vyjádřen zjevně $\mathrm{v}$ segmentu výběru (C) v analytické jednotce (III), v analytických kategoriích $(1,2,3,4)$, a to v dimenzi znalost. Ostatní kategorie analýzy mají latentní formu. Přiřadit kategorie analýzy v latentní formě je možné ještě v bodě 11 úkolů mateřských škol.

\begin{tabular}{|c|c|c|l|c|c|}
\hline \multirow{2}{*}{$\begin{array}{c}\text { RVP } \\
\text { PV }\end{array}$} & $\begin{array}{c}\text { Segment } \\
\text { výběru }\end{array}$ & $\begin{array}{c}\text { Jednotka } \\
\text { výběru }\end{array}$ & Vzdělávací oblast & Podoba & Dimenze \\
\cline { 2 - 6 } & B & (II) & $\begin{array}{l}\text { 5.4 Dítě a } \\
\text { společnost }\end{array}$ & zjevná & seznámení \\
\hline $\begin{array}{c}\text { ŠVP } \\
\text { PV }\end{array}$ & B & (II) & $\begin{array}{l}5.5 \text { Človek a svet } \\
\text { práce“, vzdělávací } \\
\text { podoblast }\end{array}$ & zjevná & $\begin{array}{c}\text { představy, } \\
\text { zkušenost }\end{array}$ \\
\hline
\end{tabular}




\begin{tabular}{|c|c|c|l|c|c|}
\hline & & $\begin{array}{l}\text { Remeslá a } \\
\text { profesie }\end{array}$ & \\
\cline { 2 - 6 } & $\begin{array}{c}\text { podoblasti } \\
\text { B }\end{array}$ & (II) & $\begin{array}{l}5.5 \text { Človek a svet } \\
\text { práce“, podoblasti } \\
\text { Technologie } \\
\text { výroby, Materiály } \\
\text { a jejich vlastnosti, } \\
\text { Konstruování, } \\
\text { Uživatelské } \\
\text { zručnosti }\end{array}$ & $\begin{array}{c}\text { zjevná } \\
\text { latentní }\end{array}$ & $\begin{array}{c}\text { vědomostí, } \\
\text { zkušeností }\end{array}$ \\
\cline { 2 - 6 } & C & (III) & (III) & - & latentní i \\
zjevná & $\begin{array}{c}\text { poznatek } \\
\text { zkušenost, } \\
\text { zredstavy }\end{array}$ \\
\hline PPP & C & znalost \\
\hline
\end{tabular}

Tab. č. 1: Umístění „požadavku“ v českém, slovenském a polském vzdělávacím programu.

\section{Závěr}

Průběh a výsledky řešení cíle (1) výzkumného šetření jsou uvedeny v oddíle 6.1. Požadavek př́ípravy na povolání ve vzdělávání dětí předškolního věku je v českých školsko-politických dokumentech formulován jako: „seznamováni dětí v předškolním vzdèláváni $s$ obsahem jednotlivých povoláni $v$ souladu s Rámcovým vzdělávacím programem pro předškolní vzděláváni" a byl identifikován v českém dokumentu Záměru 2015-2020, v jeho části označené I2) Nová opatření na podporu odborného vzdělávání, jako návrh opatření.

Zda a v jaké podobě jsou $\mathrm{v}$ aktuálně platném českém rámcovém vzdělávacím programu pro předškolní vzdělávání státní úrovně formulovány úkoly $\mathrm{v}$ oblasti připravy na povolání identifikované v českých školsko-politických dokumentech (2), bylo řešeno v oddíle 6.2.3. Stanovený cíl byl řešen kvalitativní analýzou, konstitučním přístupem. Ke kódování byly vybrány segmenty: cíle, obsah a kompetence. Kategoriemi se staly: pojem povolání, příklady povolání, označování činností v povolání; postupy v povolání; pracovní předměty a materiály; účel povolání; význam povolání; uvedení názvu objektu, v němž se povolání uskutečňuje; přímý kontakt s povoláními v autentických prostředích. Ve zjevné podobě se ,požadavek“ nachází v RVP PV v segmentu výběru B v jednotce (II) vzdělávací oblasti 5.4 Dítě a společnost v datovém úryvku: ..., „tematické hry seznamujíci dítě $s$ různými druhy zaměstnání, remesel a povolání, a v souvislosti s tím i ...s různými pracovními činnostmi a pracovními predměty, ... “ (s. 26).

Přípravu na povoláni lze podle českého RVP PV ve vzdělávání dětí předškolního věku v české mateřské škole realizovat (3) plněním tematických nabídek RVP PV, naplňováním doporučených metod a prostředků $\mathrm{v}$ užším slova smyslu a zejména př́pravou her a didakticky zacílených aktivit s odpovídajícími náměty.

„Požadavek“ ve zjevné podobě byl identifikován ve slovenském i v polském vzdělávacím programu státní úrovně (4). 
Dítě předškolního věku stojí na začátku své životní cesty. Má omezené poznatky, nemá žádné nebo má málo životních zkušeností, a to ve všech oblastech života. Uvědomělý profesionál by měl odpovědně směrovat seznamování dítěte již v jeho předškolním věku $\mathrm{s}$ celou škálou povolání. $\mathrm{S}$ těmi historickými, jejichž poznání $\mathrm{k}$ němu přichází prostřednictvím pohádek; $\mathrm{s}$ těmi, $\mathrm{s}$ nimiž se dítě může ve svém okolí bezprostředně setkat; s povoláními, která pravděpodobně zůstanou i v budoucnu, např. pekař, zemědělec, řidič, apod., a děti by měly být vedeny $\mathrm{k}$ přijetí myšlenky, že některá povolání nově vznikají a jiná zanikají. Tak, aby si dítě do doby, než přijde čas jeho rozhodování o prŕípravě na povolání, postupně o povoláních vytvořilo využitelné představy.

Bylo by prínosné pro vzdělávání dítěte $\mathrm{v}$ předškolním věku v MŠ založit a průběžně inovovat portfolio edukačních, didakticky zacílených aktivit včetně her s doporučenými prostředími a podmínkami, kde a jak aktivity s dětmi realizovat. Ve kterých by byl uveden také kontext - tedy proč učitel zvolil zrovna tuto činnost, či hru; co jí předcházelo; na co navazuje; jak dále v tématu pokračovat. Děti by získaly poznatky, zkušenosti a zároveň $i$ zážitky o současných povoláních $v$ autentických prostředích a tam, kde je to možné i o povoláních historických, a to ve všech kategoriích analýzy. A nejlépe na základě vlastní experimentace a aktuálním řešení problémů.

Byl by to př́spěvek $\mathrm{k}$ realizaci doporučujících změn pro systém vzdělávání $\mathrm{v}$ souvislosti se změnami na trhu práce uvedených v Národní iniciativě Prümysl 4.0.

\section{Literatura}

Frey, C. B, \& Osborne, M. A. (2013). The Futurue of Employment: How Susceptible are Jobs to Computeristion. In Technological Forecasting and Social Change, Dostupné z: https://www.oxfordmartin.ox.ac.uk/downloads/academic/The_Future_of_Employment.p $\underline{\text { df. }}$

Gavora, P. (2015). Obsahová analýza v pedagogickom výskume: Pohl'ad na jej súčasné podoby. In Pedagogická orientace, 25 (3), s. 345-371.

Guest, G., MacQueen, K. M., \& Namey, E. E. (2012). Applied Thematic Analysis. Los Angeles: SAGE.

Gulová, L. \& R. Šíp. (2013). Výzkumné metody v pedagogické praxi. Praha: Grada, a.s. Harbo, T. Humanizace vzdělání a současné teorie kurikula. In Pedagogika, roč. XLI, 1991, č. 3 , s. $247-255$.

Havlová, J. (1996). Profesni dráha ve 20. století. Úvod do sociologie povolání. Praha: Karolinum.

Hlad’o, P. (2008). Svět práce a volba povolání. Studijní text pro učitele. Brno: MU. Lipnická, M. \& A. Jirešová. (2007). Teoretické základy predškolskej pedagogiky. Banská Bystrica: Univerzita MB, Pedagogická fakulta.

MPO. (2018). Národní iniciativa Prümysl 4.0 [online]. [cit. 2020-07-22]. Dostupné z: https://www.google.cz/search?q=N\%C3\%A1 rodn\%C3\%AD+iniciativa+Pr\%C5\%AFmys 1+4.0.\&oq=N\%C3\%A1 rodn\%C3\%AD+iniciativa+Pr\%C $\%$ AFmysl+4.0.\&aqs=chrome.. 69i57j0.1588j0j7\&sourceid=chrome\&ie=UTF-8.

Ministerstvo školstva, vedy, výskumu a športu Slovenskej republiky. (2016). Štátny vzdelávaci program pre predprimárne vzdelávanie v materských školách. Bratislava: Štátny pedagogický ústav [online]. [cit. 2020-07-22] [online]. [cit. 2020-07-22]. Dostupné 
z: $\quad$ http://www.statpedu.sk/files/articles/nove_dokumenty/statny-vzdelavaciprogram/svp_materske_skoly_2016-17780_27322_1-10a0_6jul2016.pdf.

Ministerstwo Edukacji Narodowej. (2018). Podstawa programowa wychowania przedszkolnego dla przedszkoli, oddziałów przedszkolnych w szkołach podstawowych oraz innych form wychowania przedszkolnego [online]. Warszawa [cit. 2020-07-22]. Dostupné z: www.reformaedukacji.men.gov.pl.

MŠMT. (2014). Strategie vzdélávaci politiky České republiky do roku 2020 [online]. [cit. 2020-07-22]. Dostupné z: http://www.msmt.cz/uploads/Strategie_2020_web.pdf.

MŠMT. (2018). Rámcový vzdělávací program pro předškolní vzdělávání [online]. [cit. 2020-07-22]. Dostupné z: http://www.msmt.cz/file/39792/.

MŠMT. (2018). Zákon č. 561/2004 Sb. ze dne 24. zář́i 2004 o př́edškolním, základním, středním, vyšším odborném a jiném vzděláváni [online]. [cit. 2020-07-22]. Dostupné z: http://www.msmt.cz/dokumenty-3/skolsky-zakon-ve-zneni-ucinnem-od-1-9-2017-do-31$8-2018$.

MŠMT. (2011). Dlouhodobý záměr vzdělávání a rozvoje vzdělávací soustavy ČR na obdobi 2011 - 2015 [online]. [cit. 2020-07-22]. Dostupné z https://www.google.cz/search?ei=EkwtWqmeHNG5kwW9rqe4Ag\&q=P1\%C3\%A1n+na + roky $+2011+\mathrm{a} \% \mathrm{C} 5 \% \mathrm{BE}+2015 \&$ oq $=\mathrm{Pl} \% \mathrm{C} 3 \% \mathrm{~A} 1 \mathrm{n}+$ na + roky $+2011+\mathrm{a} \% \mathrm{C} 5 \% \mathrm{BE}+2015 \& \mathrm{~g}$ s_l=psy-ab.3..0i22i30k1.2253.2758.0.3900.1.1.0.0.0.0.84.84.1.1.0.......1.1.64.psy-

ab..0.1.84....0.G_mjQB1QSbs.

MŠMT. (2013). Nová opatření na podporu odborného vzděláváni [online]. [cit. 2020-0722]. Dostupné Z: file:///C:/Users/User/Downloads/nov\%C3\%A1\%20opat\%C5\%99en\%20na\%20podporu\% 20odborn\%C3\%A9ho\%20vzd\%C4\%9Bl\%C3\%A1v\%C3\%A1n\%C3\%AD\%20leden\%20 2013.pdf

MŠMT. (2015). Dlouhodobý záměr vzděláváni a rozvoje vzdělávací soustavy ČR na obdobi 2015 - 2020) [online]. [cit. 2020-07-22]. Dostupné na http://www.msmt.cz/vzdelavani/skolstvi-v-cr/dlouhodoby-zamer-vzdelavani-a-rozvojevzdelavaci-soustavy-3.

MPO. (2015). Národní iniciativa Průmysl 4.0 [online]. [cit. 2020-07-22]. Dostupné z: file:///C:/Users/User/Downloads/narodni-iniciativa-prumysl-40.pdf .

Povolání. (2018). [online]. [cit. 2020-07-22]. Dostupné Z https://cs.wikipedia.org/wiki/Povol\%C3\%A1n\%C3\%AD)

Strauss, A. \& Corbin, J. (1999). Základy kvalitativního výzkumu. Boskovice: Albert. Národni soustava povoláni. Dostupné z: https://www.nsp.cz/odborne-skupiny.

Vlček, P. (2015). Srovnávací výzkum v pedagogice: některé úvahy o metodologii problémového prístupu. In Pedagogická orientace, 25 (3), s. 394-412.

Vlček, P. \& Mužík, V. (2012). Soulad mezi projektovaným a realizovaným kurikulem jako faktor kvality vzdělávání v tělesné výchově. In Česká kinantropologie, 16 (1), s. 31-46. Wilson, E. O. (1993). O lidské přirozenosti. Máme svobodnou vůli, nebo je na chování ř́zeno genetickým kódem? Praha: Nakladatelství Lidové noviny.

MPSV. (2004). Zákon č. 435/2004 Sb. o zaměstnanosti [online]. [cit. 2020-07-22]. Dostupné z: https://www.zakonyprolidi.cz/cs/2004-435. 


\section{Referenční literatura}

Janik, T. \& kol. (2010). Kurikulární reforma na gymnáziích. Výsledky výzkumného šetření. Praha: VÚP.

Kalhous, Z. \& O. Obst. (2002). Kurikulum. In Školni didaktika. Praha: Portál, s. 132 - 136. Kasíková, H. \& J. Valenta. J. (1994). Reformu dělá učitel. Praha: STD.

Kovaliková, S. (1995). Kurikulum: místo zrodu změny. In Kovaliková, S. Integrovaná tematická výuka. Kroměříž: Spirála, s. 6-19.

Maňák. J. \& T. Janík. (2009). Kurikulum. In. Průcha, J. (ed.) Pedagogická encyklopedie. (s. 117 - 122). Praha: Portál, s. 117-121.

Maňák, J., Janík, T. \& V. Švec. (2009). Kurikulum v současné škole. Brno: Paido.

Opravilová, E. \& V. Gebhartová (2003). Rok v mateřské škole. Kurikulum předškolní výchovy. Praha: Portál.

Opravilová, E. \& J. Kropáčková. (2016). Předškolní pedagogika. Praha: Grada.

Pasch M. a kol. (1998). Od vzdělávacího programu k vyučovací hodině. Praha: Portál.

Průcha, J. (1997). Kurikulum: obsah školní edukace. In Moderní Pedagogika. Věda o edukačnich procesech. Praha: Portál, s. 233 - 268.

Skalková, J. (1999). Kurikulární teorie a reformy kurikula. In Skalková, J. Obecná pedagogika. Praha: ISV nakladatelství, s. $69-72$.

Walterová, E. (1994). Kurikulum. Proměny a trendy v mezinárodní perspektivě. Brno: Masarykova univerzita. 